\title{
Bridge Over Troubled Water: Finding a New Home in the Library
}

\author{
Victoria A. Elmwood \\ Loyola University, New Orleans, LA
}

\begin{abstract}
Faculty from within the disciplines interested in transitioning to academic librarianship can be a boon to libraries prepared to make the most of their skills and subject specializations.

Author Bio: Victoria Elmwood is User Experience and Instruction Librarian at Loyola University New Orleans. She has a doctorate in English and American Studies from Indiana University-Bloomington, as well as a Master's in Library and Information Science from Louisiana State University-Baton Rouge. She has taught English at Indiana University, Tulane University, the University of New Orleans, and Benjamin Franklin High School in New Orleans.
\end{abstract}

Keywords: academic librarians, alt-ac, contingent faculty, careers in higher education

\section{(c) (1)}

This is an Open Access article distributed under the terms of the Creative Commons Attribution 4.0 International License (http://creativecommons.org/licenses/by/4.0), which permits unrestricted use, distribution, and reproduction in any medium, provided the original work is properly cited. 
Most people working in higher education these days have grown disturbingly accustomed to the regular intervals at which public education funding is slashed (Mortenson, 2012, para. 3). While students find themselves being asked to make up for some of this shortfall by going more deeply into debt, universities have also absorbed these cuts by converting tenure-track positions into contingent ones, often relying overwhelmingly on part-time, adjunct, and non-tenured instructors (Committee on Contingency and the Profession, 2010, para. 3). The adjunct professor who drives between multiple campuses and relies on food stamps to make ends meet has become a commonplace of (and indispensable to) twenty-first century higher education in the United States. ${ }^{1}$

As individual tenure-track faculty lines are cut only to be replaced, hydra-like, by multiple poorly-paid adjunct positions carrying neither benefits nor job security (Bernstein and Kezar, 2016, para. 8; Shulman, 2016, p. 13), many disciplinary faculty are making the difficult choice to abandon their careers (Flaherty, 2015, para. 5; Keenan, 2014; Committee on Contingency and the Profession, 2010, para. 7). For some staring down the barrel of this unenviable decision, academic librarianship has stood out as an attractive option on what many have been calling the alt-ac (alternative academic) track, often in tones tinged with varying shades of acrimony (Boldt, 2014, para. 3; Carter, 2017, para. 4). Faculty from the disciplines have been crossing over to become library faculty for decades, but worsening trends in academic hiring may have led to a greater influx of new librarians with this kind of background. However, as the field's name suggests, academic librarianship is anything but an alt-ac

\footnotetext{
${ }^{1}$ Indeed, one recent analysis shows that the number of job postings in the humanities has been steadily declining since the turn of the 21st century, even as the number of newly-minted PhD.s continues to increase. In English, for example, the number of annual job postings has plummeted from over 1,800 in 2000 to a scant 1,000 in 2016. Yet English departments continue to churn out increasingly large numbers of new PhD.s year after year (American Academy of Arts and Sciences, 2017, Fig. 1). Though it's a crisis situation for the job seeker, the departments who must hire adjuncts to continue to function are better able to weather the vicissitudes of a shrinking budget.
} 
career. Rather, it's a career that allows former disciplinary faculty to continue doing what they do best: teaching, researching, and learning. For people whose identities, values, and hard-won credentials revolve around these pursuits, it's a profession that fits beautifully and is within their reach.

As a PhD.-holding academic dropout myself, I can say that it took me awhile to find my way to my career as an academic librarian once I gave up on higher education to stay in the city I loved and remain close to aging family members. Having meandered for several years, teaching high school, adjuncting, and proofreading advertisements, I took the advice of my sister-a cataloger-and enrolled in the distance education program from which I received my MLIS. Thanks to some difficult sacrifices and a lot of good luck, I'm currently in a tenure-track position as an academic librarian, and it's by far the best job I've ever had. If you're on a hiring committee and have the chance to interview a former professor with a terminal degree from within the disciplines, our previous career tracks will tell you a lot about what you might expect from us.

As academic librarians, former disciplinary professors bring with them a deep familiarity with scholarly communication processes and ethics, student extracurricular culture, and the very academic support units in which we will, ourselves, play a role. We excel in the librarian's duties of instruction, curricular design, faculty outreach, student mentoring, grant writing, and proposing initiatives to support faculty research. For those of us with terminal degrees in area studies or interdisciplinary fields, subject specialization that spans multiple disciplines makes us more versatile, particularly as subject librarians. Simply put, we're already at home in the professional ecosystem of higher education, making it easier for us to hit the ground running.

As much as we can bring to the table right off the bat, however, there are roles, knowledge, skills, and workplace pressures that will be new (and potentially difficult) for us. Having usually been responsible for the content, administration, and delivery of our own semester-long classes, we may be 
less accustomed to negotiating specific instructional content, whether we are embedded or teaching a one-shot session. Along the same lines, we may also struggle with coaxing the engagement of students over whom we have little substantial evaluative authority. Although we kept ourselves perpetually busy and productive in our previous careers, we may be accustomed to having large amounts of unscheduled time, as well as the freedom to spend that time working independently at home, off campus, or even out of town. The twelve-month contract term and the requirement of being on campus for a larger portion of our work hours may take some getting used to, depending on what other jobs we might have held before coming back to higher education. Moreover, years of adjuncting may have discouraged (or even actively prevented) us from attending administrative meetings or investing in the institutional governance process.

Other potential challenges and learning opportunities could include tasks such as quickly figuring out how to use new technology and software, web design or coding, writing for the web, and making a lasting impact on students despite fewer contact hours. And then there's the need to deliver quality service, which is not the same thing as teaching students. Tactfully addressing angry users wishing to dispute late fees or former peers incensed by dead links on an old LibGuide can be difficult for the disciplinary professor turned academic librarian to navigate. After all, we're accustomed to at least a grudging deference from students or a base-level civility from disciplinary faculty who were once our more immediate colleagues. Mundane duties such as fixing photocopier jams or politely asking users to refrain from browsing pornographic sites may be a new source of frustration, and it may even be difficult for some of us to acknowledge and come to terms with these feelings productively. In such cases, the attitude we choose to adopt and the support we give to and receive from coworkers can make or break the deal. This kind of newcomer to academic librarianship will need to be able to approach all range of tasks, as I did, with humility and forbearance, viewing them as both 
learning experiences and as part and parcel of the librarian's responsibility to her coworkers and to the academic community of which she is so vitally a part.

The challenges of this new professional arena should be mere speed bumps for this subset of second-career librarians, so long as we invoke the intellectual curiosity, capacity for learning, and sustained commitment to education that brought us to academia in the first place. For anyone considering such applicants, a crucial task will be to determine how willing and able they are to access these traits in the context of their new career track. In addition, as with any early-career new hire, our chances for success will be bolstered significantly by effective mentoring, support for professional development and research, and a clearly established set of performance expectations.

\section{References}

American Academy of Arts and Sciences. (2017). A path forward as academic job market in humanities falters. Retrieved from https://www.amacad.org/content/research/dataForumEssay.aspx?i=22902

Bernstein, S., \& Kezar, A. (2016). Is it time to eliminate tenure for professors? The Conversation.

Retrieved from http://theconversation.com/is-it-time-to-eliminate-tenure-for-professors-59959

Boldt, J. (2014). What's your favorite alt-ac resource? ChronicleVitae. Retrieved from https://chroniclevitae.com/news/366-what-s-your-favorite-alt-ac-resource

Carter, R. S. (2017). Alt-ac careers: Academic librarianship [Blog post]. Retrieved from https://www.insidehighered.com/blogs/gradhacker/alt-ac-careers-academic-librarianship Committee on Contingency and the Profession. (2010). Tenure and teaching-intensive appointments. Retrieved from https://www.aaup.org/report/tenure-and-teaching-intensive-appointments 
Dreger, A. (2015). The disappearance of tenure-track jobs is a recipe for useless research and weak teaching. Quartz. Retrieved from https://qz.com/799558/the-disappearance-of-tenure-track-jobsis-a-recipe-for-useless-research-and-weak-teaching

Flaherty, C. (2015). Public good-byes: Essays from academics fed up with higher ed mark resurgence of "quit lit." Inside Higher Ed. Retrieved from https://www.insidehighered.com/news/2015/09/09/essays-academics-fed-higher-ed-markresurgence-quit-lit

Keenan, E. (2014). Leaving academia? It's time to have "the talk." ChronicleVitae. Retrieved from https://chroniclevitae.com/news/434-leaving-academia-it-s-time-to-have-the-talk

Lee, O. (2015). I have one of the best jobs in academia. Here's why I'm walking away. Vox. Retrieved from https://www.vox.com/2015/9/8/9261531/professor-quitting-job

Mortenson, T. G. (2012). State funding: A race to the bottom. Retrieved from http://www.acenet.edu/the-presidency/columns-and-features/Pages/state-funding-a-race-tothe-bottom.aspx

Shulman, S. et al. (2016). Higher education at a crossroads: The economic value of tenure and the security of the profession. Academe, 102(2), 9-23. Retrieved from https://www.aaup.org/sites/default/files/2015-16EconomicStatusReport.pdf 